\title{
Globalisation and the Postcolonial World
}




\author{
Also by Ankie Hoogvelt \\ THE SOCIOLOGY OF DEVELOPING SOCIETIES \\ THE THIRD WORLD IN GLOBAL DEVELOPMENT \\ MULTINATIONAL ENTERPRISE: An Encyclopedic Dictionary \\ of Concepts and Terms (with A. Puxty)
}




\title{
Globalisation and the Postcolonial World
}

\author{
The New Political Economy \\ of Development
}

Ankie Hoogvelt

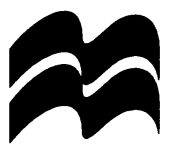




\section{$m$}

(C) Ankie Hoogvelt 1997

All rights reserved. No reproduction, copy or transmission of this publication may be made without written permission.

No paragraph of this publication may be reproduced, copied or transmitted save with written permission or in accordance with the provisions of the Copyright, Designs and Patents Act 1988, or under the terms of any licence permitting limited copying issued by the Copyright Licensing Agency, 90 Tottenham Court Road, London W1P 9HE.

Any person who does any unauthorised act in relation to this publication may be liable to criminal prosecution and civil claims for damages.

The author has asserted her right to be identified as the author of this work in accordance with the Copyright, Designs and Patents Act 1988.

First published 1997 by

MACMILLAN PRESS LTD

Houndmills, Basingstoke, Hampshire RG21 6XS

and London

Companies and representatives

throughout the world

ISBN 978-0-333-46106-8 ISBN 978-1-349-25671-6 (eBook)

DOI 10.1007/978-1-349-25671-6

A catalogue record for this book is available from the British Library.

This book is printed on paper suitable for recycling and made from fully managed and sustained forest sources.

$\begin{array}{rrrrrrrrrr}10 & 9 & 8 & 7 & 6 & 5 & 4 & 3 & 2 & 1 \\ 06 & 05 & 04 & 03 & 02 & 01 & 00 & 99 & 98 & 97\end{array}$

Copy-edited and typeset by Povey-Edmondson

Okehampton and Rochdale, England 


\section{Contents}

List of Figures and Tables ix

Preface $\quad \mathrm{x}$

\section{PART I HISTORICAL STRUCTURES}

Introduction $\quad 3$

International political economy 6

The critical theory of Robert Cox: historical structure $\quad 10$

$\begin{array}{ll}\text { Historical structure and stage theory } & 12\end{array}$

1 The History of Capitalist Expansion 14

The political nature of the capitalist world economy $\quad 15$

The dialectical development of capitalism as a world system

A periodisation of capitalist development and expansion

The mercantile phase of European expansion $\quad 17$

$\begin{array}{ll}\text { The colonial phase of European expansion } & 18\end{array}$

Marxist theories of capitalist imperialism 21

Critiques of Marxist theories of imperialism 25

2 Neo-colonialism, Modernisation and Dependency 29

Global economic pressures $\quad 29$

Domestic tensions $\quad 32$

Geo-political relations $\quad 33$

Modernisation theory $\quad 35$

Dependency theory $\quad 37$ 
3 Crisis and Restructuring: The New International Division of Labour

Material capabilities: global Fordism $\quad 45$

Neo-colonial economic relations $\quad 47$

Economic nationalism in the Third World 48

Changing geo-political relations 51

Critical theory: diversity and micro-studies $\quad 53$

Gender and development 54

'Dependency associated' development theory · 57

Postimperialism and world system theories 58

\section{PART II GLOBALISATION}

$\begin{array}{lr}\text { Introduction } & 65\end{array}$

4 From Expansion to Implosion 69

World trade: long-term trends 69

Foreign direct investment (FDI) and the growth of multinational enterprises

World capital flows: long-term indirect investments

Global financial deepening and the structural position of the Third World

Core-periphery: from structural exploitation to structural irrelevance

\section{From Fordist to Flexible Production}

Fordism

From Fordist to flexible production $\quad 93$

The Japanese mode of regulation

Internationalisation or globalisation? The Japanese model in the world economy

The Regulation School

Flexible production and global markets

Flexible production and global enterprise organisation $\quad 110$

Flexible production and global capital-labour relations 
The sociology of globalisation

Roland Robertson: world compression and intensification of global consciousness

David Harvey: Time/space compression

Anthony Giddens: Time/space distantiation

The economics of globalisation

A global market discipline

Flexible accumulation through global webs 125

Global financial 'deepening'

\section{Global Regulation}

Capital-state relations: global governance and the internationalisation of the state

Capital-labour relations: the new global world of work

Core-periphery relations

The politics of exclusion

\section{PART III THE POSTCOLONIAL WORLD}

\section{Introduction}

The postcolonial: condition and discourse

Postcolonial formations

8 Africa: Exclusion and the Containment of Anarchy

Debt and the internationalisation of capital

Financial integration and deregulation

Debt crisis and solutions: the 1980s

The role of the IMF and the World Bank

Dismantling the developmental state

Structural adjustment in Africa: the social and economic record

Structural adjustment: intensifying global relations

Democracy and economic reform

The reverse agenda of aid and global management 
$\begin{array}{lr}\text { Spiritual renewal } & 185\end{array}$

The West confronts Islam 188

Education and Orientalisation 191

The failure of dependent development 193

The rise of Islamist new intellectuals and the politics of anti-developmentalism

10 The Developmental States of East Asia 201

The role of the state in economic development 203

Theories of the developmental state 205

Comparative political economy 208

International political economy 210

Limits of the East Asia developmental model 213

Regionalisation: the next lap? 216

11 Democracy, Civil Society and Postdevelopment in Latin America

The Latin American intellectual left 221

Postwar developmentalism and dependency theory 223

Military regimes, internationalisation and US imperialism

The dance of the millions $\quad 227$

The new democracy: state, civil society and market reforms

Civilian rule and political democracy

The new social movements and civil society 233

Imagining postdevelopment

Conclusion

Reconstructing universalism, regional mercantilism or postdevelopment? 


\section{List of Figures and Tables}

Figures

4.1 Widening gaps in per capita income, 1860-1989. Weighted shares of world income of developed and underdeveloped groups of countries

10.1 The economic growth of the world's regions

\section{Tables}

4.1 The ratio of commodity world trade to world output, 1800-1993 (per cent)

4.2 Share of commodity world trade between economic areas, $1800-1990$ (per cent)

4.3 Inter- and intra-group trade, 1876-1990

4.4 The world population among groups of countries, 1800-1990

4.5 Gross capital flows, 1980-90 


\section{Preface}

My intention when I embarked on writing this book was to provide an account and assessment of recent trends in world political economy and the development prospects of the Third World within it. It would serve as a successor volume to my 1982 book The Third World in Global Development. Changing realities, however, have proved a hard taskmaster. Development Studies no longer exists as a body of knowledge with a coherent identity, or even coherent identities, as in competing schools of theory or paradigms. It no longer has pretensions of being or becoming a full-blown academic discipline but rather is gradually being replaced by, or is merging into, other subjects. In the words of one of its pioneers, Dudley Seers, 'Development Studies is over the hill or downright dead'.'

The idea of a Third World never proved an entirely satisfactory analytical category for understanding the economic, social and political conditions of the countries of Africa, Latin America and Asia. For much of the period following the Second World War, however, it was a very useful way of summarising the common experiences and attitudes of the countries of these regions. The demise of the concept today has effectively mirrored the dissolution of the Third World itself, as some regions of the Third World have shamed the pundits of doom by becoming the dynamic growth centres of the world economy (East Asia), and others have declined to the point of extinction, snuffing out all belief in progress. As Wolfgang Sachs writes: 'The idea of development was once a towering monument inspiring international enthusiasm. Today, the structure is falling apart and in danger of total collapse'. ${ }^{2}$

In the early 1980s Development Studies became stranded in what was widely referred to as 'the Impasse'. Work in the field of development studies fragmented into a diverse range of intellectual pursuits without any sense of common direction or purpose. First, it fragmented into area studies, in which the success of the East Asian 
'developmental' states offered a promising focus for theoretical renewal albeit rather more for the field of comparative political economy than for development studies itself. Second, there were meta-theoretical critiques of those theoretical constructs that had long constituted the toolbox of development theory. Dependency, exploitation, unequal exchange, mode of production, modernisation, rationalisation, progress - all these came under the deconstructing axe of postmodernists, post-marxists and poststructuralists alike. Third, much work on development issues became subsumed in the field of international political economy literature, focusing in particular on issues of debt, poverty and peripheralisation, perceived as the downside of a quickening process of globalisation of the world economy. Fourth, a strong surge of interest in gender relations provided a welcome relief from the tedium of class relations that had dominated much of the development agenda previously. Fifth, in engaging with Environmental Studies, some development literature came to focus on poverty in the poor world as even more damaging to 'our' ozone layer than the pursuit of wealth in the rich world.

This, certainly, is not an exhaustive list, but it serves to show how Development Studies has been scattered by the winds of change over a wide terrain of intellectual enquiry, making the task of synthesis $a$ priori impossible. What then should be the purpose of writing a general introductory text on the subject? And if one did find such purpose, how would it help organise the sequencing of chapters in a manner that will ensure that at least some of the new agendas are incorporated in a coherent way?

It seems to me that a chief purpose should be to understand the processes of crisis and transformation of the world economy that constitute the winds of change that are now blowing development studies into different directions. Without such understanding we will lose sight of the continuity in change of the historical process. Today there are over 1.2 billion people in the world living in absolute poverty and misery, and their number is growing, increasingly enveloping those who previously formed part of the rich, First World, and of the semi-developed Second World. ${ }^{3}$ Furthermore, the gap between the richest and poorest quinquile of the world's population is twice as big today than it was 30 years ago. ${ }^{4}$ On the other hand, it is also the case that some countries, notably in East Asia, have grown, and are still growing, very fast indeed and that 
they have managed to translate that growth into improved standards of living for the masses of the population. However, the rising fortunes of new regions or groups of countries in the world economy, and the decline of others, should not blind us to the way that wealth and poverty are connected. I remain convinced that poverty and wealth-creation are but two sides of the same historical process, even if that historical process itself undergoes fundamental changes in the manner in which it is organised. But when the understanding and interpretation of wealth and poverty themselves become fragmented, divorced from one another as they are today, there is a danger that rather than working to eradicate poverty we shall end up, in true postmodern style, celebrating it as a form of 'difference'.

While there is continuity in the fact that wealth and poverty creation are connected, it is nevertheless one of the main organising themes of the book that at the present time we are experiencing a complete, radical break, a qualitative change, in the historical development of capitalism. The world economic crisis which began in the 1970s has led, not just to a restructuring of the world economy, but to a major transformation of the way in which production and distribution is organised. There is a new political economy in the making. But, in contrast to the past, this new political economy is not a political economy that first developed and became organised within one specific territorial space and next expanded outward; rather it is a new political economy that is global from the very beginning. This has consequences for our understanding of the locational distribution of wealth and poverty, of development and underdevelopment. The familiar pyramid of the core-periphery hierarchy is no longer a geographic but a social division of the world economy. The designation 'postcolonial' world in preference to 'Third World' serves to articulate at once the shift from national origin to subject-position in the global political economy and a movement beyond a specific period in history, that of colonialism and Third World nationalist struggles.

\section{Outline of the Book}

As the subtitle suggests, the book is about the new political economy of development. These very words beg at least two questions: one, 
that there is an understood and generally accepted meaning of the term 'political economy', and two, that there is an old version of it, now distinct from and discarded by different interpretations. As we shall see in the introduction to Part $I$, there is no such thing as a unified methodology or theory of political economy. What there is is a set of questions about the relationship between power and wealth, between politics and economics, between states and markets. Depending on how this relationship has been understood and conceptualised, different theories of world order have held sway for a considerable time, namely realism, institutionalism and Marxism/ structuralism. Their common ground was the state/market interaction as the embodiment of politics and economics in the modern world. And a central question became how to grasp the conflicting logic of an evolving and progressively integrating world market, on the one hand, with the continuing compartmentalisation of the world political order into sovereign nation-states on the other.

Within the Marxist structuralist tradition the evolving international state/market nexus was analysed in terms of the dialectical development of capitalism in historical periods. Capitalism's inherent contradictions were said to be worked out in different phases of expansion, punctuated by crises, in which state and interstate relations were time and again rearranged as political structures that held in place the exploitative economic relationship between core and peripheral economies. In Chapters 1, 2 and 3, we look back on this tradition from the vantage-point of Robert Cox's critical theory of historical structures. Thus each phase of capitalist expansion is described in turn and we review the theories that emerged whether as hegemonic, legitimating, ideology or as counter-hegemonic critique, within each evolving phase. In this way the historical specificity of theories of imperialism, of modernisation and dependency, of postimperialism and world system, and of the New International Division of Labour, will become clarified.

Part II begins, in Chapter 4, with a statistical portrait of the dialectical development of capitalism over the past two hundred years. We discover that world trade and capital flows, while at first expanding to embrace ever more areas of the world, gradually turned into a process of implosion when capital relations became intensified within the core while selectively withdrawing from the periphery. Meanwhile this process resulted in cumulatively growing differences in income between rich and poor nations. 
The historically generated structure of deepening inequality provides the backdrop for our understanding of the present crisis and transformation debate to which we turn in subsequent chapters. By the 1970s, capitalism had reached the limits of its own expansion and this became the crucible of fundamental change. This change is becoming visible in an information-technology driven new political economy that characterises the production process and its global, though not world-wide, embrace. In Chapter 5 we discuss the changes in economic production and industrial organisation which are today widely referred to as flexible production. Using the theory and the research agenda of the Regulation School, we note that there is a new techno-economic paradigm that gives structural direction to the process of social transformation but which requires an appropriate mode of regulation before a new regime of accumulation can be achieved. I shall argue that the structural properties of the new techno-economic paradigm point towards a mode of regulation which is likely to be global from the outset.

Chapters 6 and 7 discuss the global aspects of the process of transformation. Pertinently, in contributing to a theory of globalisation, I privilege the sociology of globalisation over the economics of globalisation. I argue that the reconstitution of the world into a single social space today drives the economics of globalisation even though the preceding period of economic internationalisation has itself created the conditions for the emergence of this single social space. The contemporary process of globalisation signals a 'higher' level of intensifying economic, financial, cultural and social crossborder networks than before. It is accompanied by processes of disintegration, as old structures of political power and social and economic organisation are being eroded, and new ones are slowly being formed. Here is the locus of the current crisis and transformation experience. Ever larger segments of the world population, both inside the advanced countries, but more numerous still inside the Third World, are being expelled from the emerging 'thickening' network of human social and economic interaction. Rather than being an expansive process, the present process of globalisation appears to be an imploding or shrinking one.

Part III of the book addresses the implications of globalisation for the postcolonial world. The term postcolonial is a very recent arrival to development literature. It is a term of complex origins which we shall explore in the introduction to the final part of the book. For 
now, it suffices to note that the concept has merits simply because it groups together all formerly colonial societies despite differences in their relation to the global capitalist system, while at the same time offering a point of entry for the study of those differences. This point of entry is the 'aftermath' of the colonial relation and the manner in which this becomes reconstituted and contested in the process of the present transformation of the global political economy. Thus we may study the postcolonial condition as a state of being that is the combined outcome of external pressures (globalisation, the post-cold war order, and so forth) and locally and historically specific characteristics and struggles arising out of the (neo)colonial relation.

I consider four types of postcolonial 'conditions' or 'situations' or 'social formations', each exemplified in one of four regions of the world, though not necessarily exclusive to it. Neither are these four exhaustive of all social formations in the postcolonial world. There are plenty of postcolonial conditions which we do not discuss in this book, for example India, China and South Africa. We shall examine in turn the following regions and conditions: Sub-Saharan Africa - exclusion and anarchy (Chapter 8); the Middle East Islamic revolt and anti-developmentalism (Chapter 9); East Asia State-led developmentalism and regionalisation (Chapter 10); and Latin America - Democracy, civil society and postdevelopment (Chapter 11).

To write about so many different parts of the world is an audacious undertaking. It would not have come to pass had it not been for the inspiration and help, direct and indirect, that has been given to me by my research and graduate students who after all are a pretty international bunch. They have taught me many things I didn't know and brought to my attention literatures that I had never read. Where appropriate I have referred to their theses in the normal way through references in the text. Any errors or flaws however are all mine. Here I want to thank them, Masae Yuasa, Rongyan Qi, Lucy Walker, Gillian Koh, Rachel Tibbett, Dong Sook Gills, Fithri Othman, Anne Holgate Lowe, Mark Christian and many others, for pushing me all the time to keep up with them. In so doing they have turned teaching into a real learning experience and a delightful vocation!

It astonishes me that in these times of intensified workloads, and ever more oppressive working conditions in universities, one can still 
find colleagues willing to sit down and wholly selflessly go through some half-baked manuscript, make meticulous comments and constructive criticisms and tune their minds to somebody else's intellectual problems. I am deeply grateful to my colleagues Tony Payne, Lena Dominelli, Dave Phillips and Nick Stevenson, who each have gone through all or various bits of earlier drafts and made helpful comments and encouraging suggestions as I went along. Naturally they are relieved of any responsibility for the contents, even though without them I might not have completed the task.

If I mention her last it is not because of her contribution being least, but because hers happened to come at the very end of all the other work: scrubbing the text clean and making it presentable to the publisher. Marg Walker has given the manuscript the precision and care that it was in danger of losing when I hurried towards the deadline. I thank her for her support and patience. 